\title{
Histological Study of the Harderian Gland of Pati Duck (Anas platyrhynchos domesticus) of Assam during Postnatal Development
}

Jiten Rajkhowa, Kabita Sarma, Snehangsu Sinha

10.18805/IJAR.B-4768

\begin{abstract}
Background: The farmers are rearing duck in small scale in semi intensive system without investing more capital but it contributes a major part to uplift the socio-economic condition of the rural poor people of Assam. The Pati duck (Anas platyrhynchos domesticus) population constitutes a major indigenous non-descript economically important duck variety in the state of Assam. The Harderian gland acts as a part of the head associated lymphoid tissue (HALT) and provides local innate immunity to the upper respiratory system, to the eye and oral cavity. Since literature on histological study of Harderian gland of Pati duck is scant, hence the present study was designed to establish the basic histological details on Harderian gland at different stages of postnatal development of Pati duck of Assam.

Methods: The present study was conducted on total forty five (45) numbers Pati duck of Assam at different stages of postnatal development. The experimental birds were brought to the Department of Anatomy and Histology, College of Veterinary Science, Assam Agricultural University, Khanapara, Guwahati-22 and was sacrificed according to the method of Gracy (1986). For histological study the tissue samples from the Harderian gland of all the age group were fixed in $10 \%$ neutral buffered formalin solution and processed to prepare paraffin blocks as per the procedure described by Luna (1968). The paraffin blocks were sectioned in Shandon Finesse microtome in $5 \mu \mathrm{m}$ thickness and the sections were stained by different methods as described by Luna (1968).

Result: The Harderian gland of Pati duck had a capsule, the thickness of the capsule of the Harderian gland was increased slightly along the advancement of the age. The capsular connective tissue penetrated the parenchyma of the Harderian gland in the form of septa. The collagen, reticular, elastic and nerve fibers were observed along with the capsule and as well as in the septa. The Harderian gland of the Pati duck was compound tubular gland. The columnar epithelial cells lined the tubules. There was no cortex and medulla in the gland and the tubular structure were uniformly distributed within the lobules. A central canal was present in the gland which converged to the duct of the gland. The lymphocytes, plasma cells were found in the intertubular connective tissue. The numbers or population of plasma cell and lymphocytes were accelerated by the advancement of age. The myoepithelial cells with spindle shaped nucleus were present near the basement membrane close to the secretary cells. The histology of the duct of the Harderian gland of Pati duck was like that of typical hollow tubular organs. There were few lymphatic nodules very distinctly present extended from the lamina propria to the muscle layer.
\end{abstract}

Key words: Harderian gland, Histology, Pati duck, Postnatal.

\section{INTRODUCTION}

The Pati duck population constitutes a major indigenous non-descript duck variety in the state of Assam. The Annual egg production per Pati duck is 70-95 eggs, (Kalita et al., 2009). The indigenous duck variety of Assam is the only duck enlisted in the website of the bureau under the name 'pati' (0200 PATI 11001) of Animal Genetic Resources. Harder, (1694) reported his discovery of a 'glandula nova lachrymalis', suggesting that the large structure he had identified in deer server to moisten the surface of the eye, the Harderian gland. It has been held to be a site of immune responses, a source of thermoregulatory lipids, a source of pheromones, a photoprotective organ and part of a retinalpineal axis (Payne, 1994 ). Since there is scanty of literature on histological study of the postnatal development of Harderian gland of Pati duck of Assam, hence the present study was designed to establish the basic histological norms on Harderian gland at different stages of postnatal development of Pati duck of Assam.
Department of Anatomy and Histology, College of Veterinary Science, Assam Agricultural University, Guwahati-781 022, Assam, India.

Corresponding Author: Jiten Rajkhowa, Department of Anatomy and Histology, College of Veterinary Science, Assam Agricultural University, Guwahati-781 022, Assam, India.

Email: drjitenrajkhowa@gmail.com

How to cite this article: Rajkhowa, J., Sarma, K. and Sinha, S. (2022). Histological Study of the Harderian Gland of Pati Duck (Anas platyrhynchos domesticus) of Assam during Postnatal Development. Indian Journal of Animal Research. DOI: 10.18805/IJAR.B-4768.

Submitted: 08-09-2021 Accepted: 05-01-2022 Online: 19-02-2022

\section{MATERIALS AND METHODS}

The present study was conducted on Pati duck of Assam at different stages of postnatal development $(n=45)$. The Ducks were divided into five as age group $0,4,16,24$ and 42 weeks.

For histological study the tissue samples from the Harderian gland of all the age group were fixed in $10 \%$ 
neutral buffered formalin solution and processed to prepare paraffin blocks as per the procedure described by Luna (1968). The paraffin blocks were sectioned at $5 \mu \mathrm{m}$ thickness with the Shandon Finesse microtome. The tissue sections were stained by different methods as described by Luna (1968). The following staining methods were carried out in the present histological study:

a. Mayer's Haematoxylin and Eosin stain.

b. Van Gieson's method for collagen fibres.

c. Gomori's method for reticular fibres.

d. Hart's method for elastic fibres.

e. Bielschowsky's method for nerve fibers.

Different micrometrical parameters were recorded on Hematoxylin and eosin stained sections by means of standard method of micrometry using Nikon E 200 camera mounted microscope and Image Pro Express Ver-2.0 Software. The data were analysed using the Statistical Analyses System version 9.3 (SAS 2012) for Microsoft Windows.

\section{RESULTS AND DISCUSSION}

The Harderian gland of Pati duck was covered by a capsule consisted of connective tissue, blood vessels, nerves and lymphatices ( Fig 1 and 2). The similar finding was reported by Brobby (1972) in duck, Liman and Gülmez (1996) in domestic geese and Mobini, (2012) in native chicken. The thickness of the capsule of the Harderian gland increased slightly along the advancement of the age. The capsular connective tissue penetrated the parenchyma of the Harderian gland in the form of septa (Fig 2). The thickness of the septal connective tissue also increased from 0 weeks to 42 weeks age group. The average thickness of the capsule of the Harderian gland of Pati duck is shown in the Table 1. Similar finding were observed by Mobini, (2012) in native chicken; Kleækowska-Nawrot, et al. (2015) in Ostrich; Ali et al. 2016 in pigeon and Bejdic et al. 2018 in laying hens. In the capsule a noticeable amount of connective tissue and nerve fibers were present in all the age group of duck. The amount of collagen fibers present in the capsule and as well as in the septa were increased from 0 weeks to 42 weeks age group i.e. distribution of the fibers became more prominent along the advancement of the age (Fig 3). The distribution of the fibers gradually decreased from capsule to septa towards the centre of the gland. The reticular fibers were observed very prominent in inter lobar, inter lobular and in between tubules rather than the capsule. The reticular fibers were very fine, form the net work along the tubular

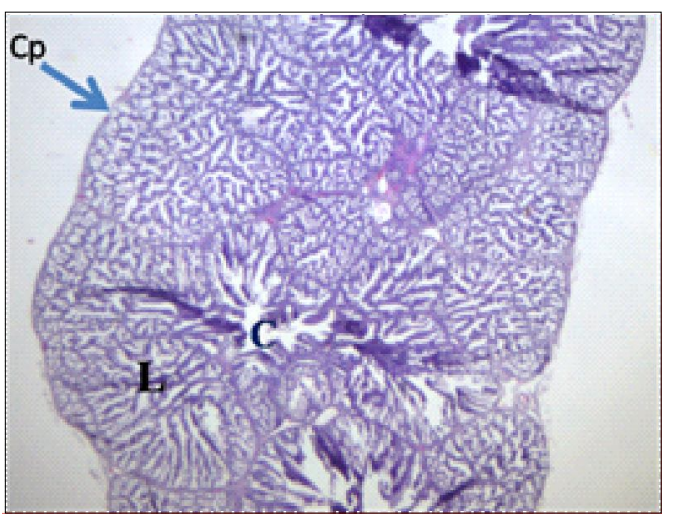

Fig 1: Photomicrograph showing the capsule $(C p)$, central cannal $(\mathrm{C})$, lobe $(\mathrm{L})$ in the Harderian gland of Pati duck, 4 weeks (H\&E, 4X).

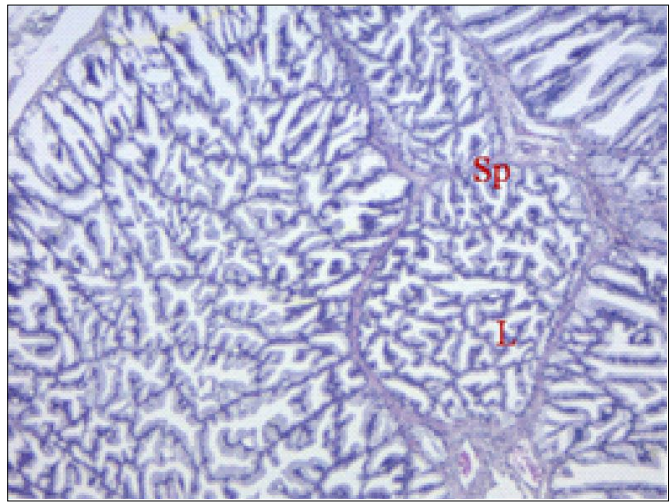

Fig 2: Photomicrograph showing the capsule (Cp), septa (Sp), Lobule $(L)$ of the harderian gland of Pati duck of 16 weeks. (H\&E at 10x).

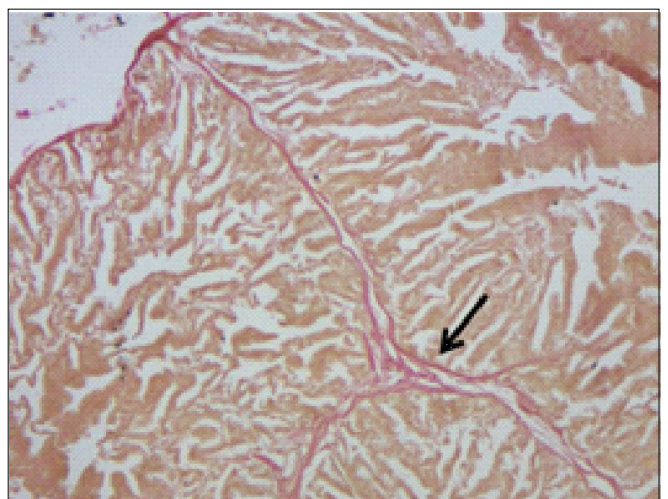

Fig 3: Photomicrograph of showing the collagen fibers of the Harderian gland of Pati duck 24 weeks. (10X, Van Gieson's).

Table 1: The average (Mean \pm SE) thickness of the capsule, the diameter of the primary, secondary and tertiary tubules and the height of the tubular epithelium in $(\mu \mathrm{m})$.

\begin{tabular}{lccccc}
\hline Age group & Capsule & Primary tubules & Secondary tubules & Tertiary tubule & Epithelium (height) \\
\hline 0 week & $5.83 \pm 0.80$ & $62.50 \pm 5.04$ & $42.20 \pm 2.97$ & $32.50 \pm 3.02$ & $14.20 \pm 0.43$ \\
4 week & $7.63 \pm 0.48$ & $74.00 \pm 7.58$ & $46.80 \pm 1.36$ & $33.60 \pm 1.05$ & $14.35 \pm 0.37$ \\
16 week & $11.20 \pm 0.86$ & $98.53 \pm 8.92$ & $59.33 \pm 5.03$ & $34.28 \pm 2.20$ & $14.80 \pm 0.52$ \\
24 week & $13.00 \pm 2.55$ & $105.67 \pm 7.87$ & $68.37 \pm 2.82$ & $34.82 \pm 3.72$ & $15.12 \pm 0.87$ \\
42 week & $13.52 \pm 0.76$ & $117.38 \pm 9.75$ & $72.16 \pm 4.19$ & $41.17 \pm 2.48$ & $15.48 \pm 0.42$ \\
\hline
\end{tabular}


core beneath the epithelium (Fig 4). The elastic fibers were found along with the capsule, septa in an increasing trend along with the advancement of age (Fig 5). The nerve fibers of the Harderian gland were noticed in the capsular, inter lobar and inter lobular connective tissue and extended up to the base of the lining epithelium (Fig 6). The present findings were in accordance with the findings of Brobby (1972) in the Harderian gland of domestic duck, Mobini, (2012) in domestic chicken; Klećkowska-Nawrot, et al. (2015) in the Harderian gland of Ostrich.

The Harderian gland of the Pati duck was compound tubular gland. Payne (1994) and Chieffi et al. (1996) also reported that the Harderian gland was usually compound tubulo-alveolar type, but sometimes it might also be compound tubular in avian species. From the capsular connective tissue of the periphery, the primary tubules were radiating towards the inner side of the gland and then the secondary tubules emerged from the primary tubules and then the tertiary tubules (Fig 7). The tertiary tubules were ended at an apical ending or sometimes it was connected to other tertiary tubules and look like a network of tubules inside the lobules. The tertiary tubules which were at the middle or centre of the gland they had the free apical end

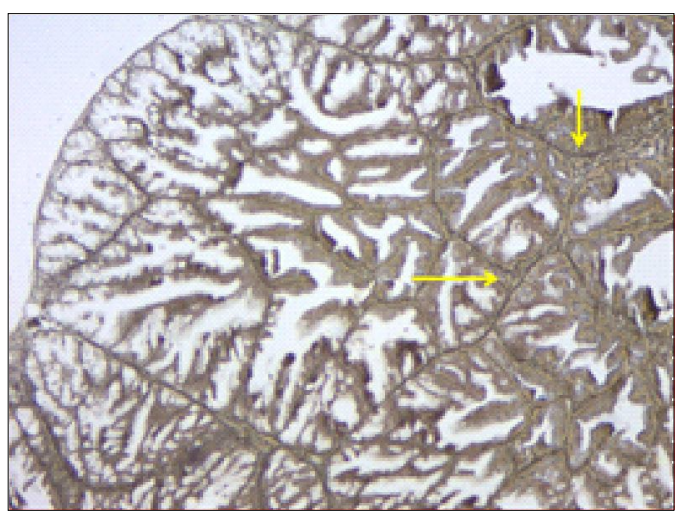

Fig 4: Photomicrograph showing the reticular fibers of the Harderian gland of Pati duck of 4 weeks (10X, Gomori).

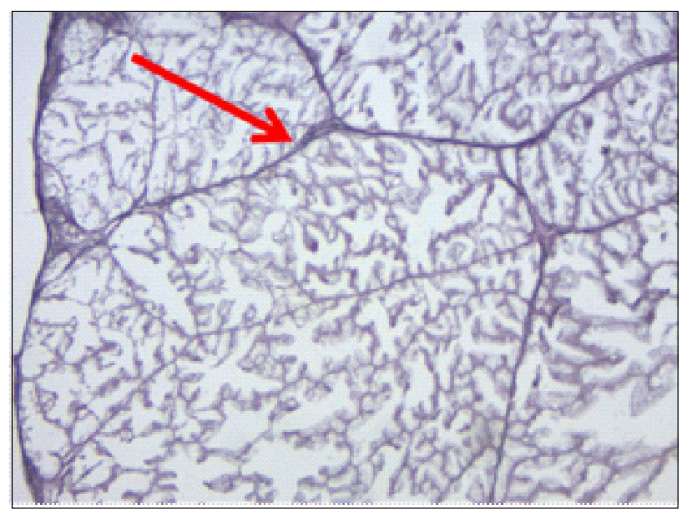

Fig 5: Photomicrograph showing the Elastic fibers of the Harderian glang of Pati duck of 16 week age group. (Hart's, 10X). piece and which indicated the future expansion of the gland (Fig 7).

The columnar epithelium cells lined the tubules. The present findings were in agreement with the finding of Brobby (1972) in domestic duck. The tubules were irregular in shape and size and there were wide lumen within the tubules. These tubules were distributed with in a lobule and such several lobules together formed the lobe and then the gland. There was a central cannel in each lobule. There was no cortex and medulla in the gland, the tubular structures were uniformly distributed within the lobule. The central cannel ultimately converged to the main duct of the gland. The Harderian gland was composed of many lobules arranged around a central cannel and each lobule contained a central lumen and corpus or body reported by Boydak and Aydin (2009) in domestic geese, Kozlu et al. (2010) in the osprey, Dimitrov, (2012) in guinea fowl and Indu et al., (2014) in the Harderian gland of White Pekin duck.

The primary tubules divided to several secondary tubules after a short distance from the periphery. The secondary tubules and the tertiary tubules were connected to other such tubules. It was difficult to recognize and differentiate the Primary, Secondary and Tertiary tubules.

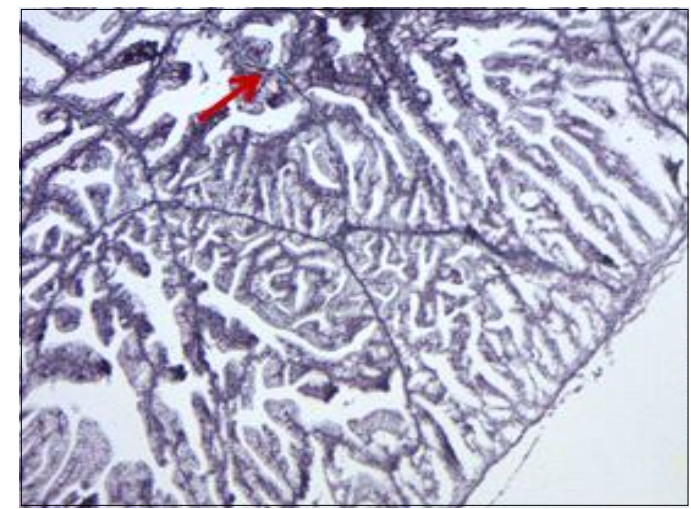

Fig 6: Photomicrograph showing the nerve fibers of the Harderian glang of Pati duck of 24 weeks age group. (Bielschowsky's, 10X).

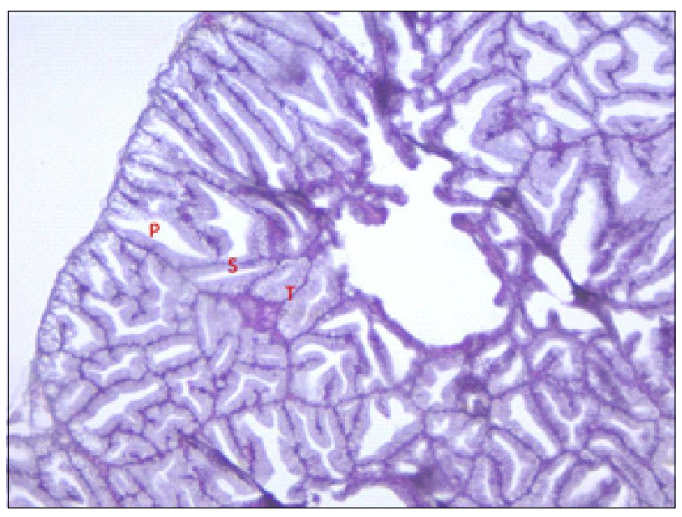

Fig 7: Photomicrograph showing primary $(P)$, secondary $(S)$ and tertiary $(T)$ tubules of the harderian gland of Pati duck of 0 week. ( $H \& E, 10 X)$. 
The average thickness of the capsule, diameter of the Primary, Secondary, Tertiary tubules and the height of the tubular secretary epithelium were recorded and shown in the Table 1. Similar results were reported by Dimitrov, (2012) in the Harderian gland in helmeted guinea fowl. In the present study, the capsular thickness and the diameter of the tubules showed a uniform increased trend along with the advancement of the age. The height of the tubular epithelium increased slightly, remained almost same in all the age group.

The lining epithelium was simple columnar and the oval or round nucleus was present near the basement membrane. The nucleus of the secretory cell was darkly stained in routine H\&E staining. The cytoplasm of the cells occupied by mucous secretion of the cell so during the routine staining procedure the apical portion of the cells gave an appearance of an empty space (Fig 8). Some of the secretory cell projected in the central canal took stain homogenously. The finding of the present study was supported by the findings of Brobby (1972) in domestic duck, Klećkowska-Nawrot et al. (2015) in the Harderian gland of Ostrich; Ahmed et al. ( 2016 ) in chameleons and Bejdić et al. (2018) in the Harderian gland of laying hen.

In the inter tubular connective tissue the lymphocyte, plasma cells were present and population of these cells were increased towards the central canal and their's numbers accelerated by the advancement of age (Fig 9, 10). These inter tubular connective tissue (core) converged to form inter lobular connective tissue and looked like a network. A triangular like area was formed by merging of inter lobular connective tissue where the lymphocyte, plasma cell and myoepithelial cells were more densely populated. Altunay and Kozlu (2004) and Ali et al. (2016) reported the presence of myoepithelial cells with darkly stained flat nucleus surrounding the secretary cells in the Harderian gland of Ostrich and Chameleons respectively. In the present investigation it was observed that the aggregation of the lymphocytes in inter tubular space showed an increasing trend from 0 weeks to 42 weeks age group. This was due to the gradual exposure to the antigens present in the environment with advancement of age of the birds. Bejdic et al. (2014) also reported an increased trend of the lymphocyte and plasma cell in the Harderian gland of laying hens.

The duct of the Harderian gland of Pati duck was hollow tubular organ and consisted of the typical histological layers. The lining epithelium was columnar varying in height. The nucleus was round or oval and placed towards the basal border. The cytoplasm was homogenous and in some cells vacuole was observed at the apical border. The lamina propria consisted of areolar connective tissue with aggregated lymphocytes. The lamina muscularis mucosae was interrupted as some lymphatic nodules passed from the lamina propriya to submucosa (Fig 11). The blood vessels, nerve fibers, connective tissue fibers and lymphatics were observed in sub mucosa as well as in the lamina propria. Burns and Maxwell. (1979) reported the duct of the

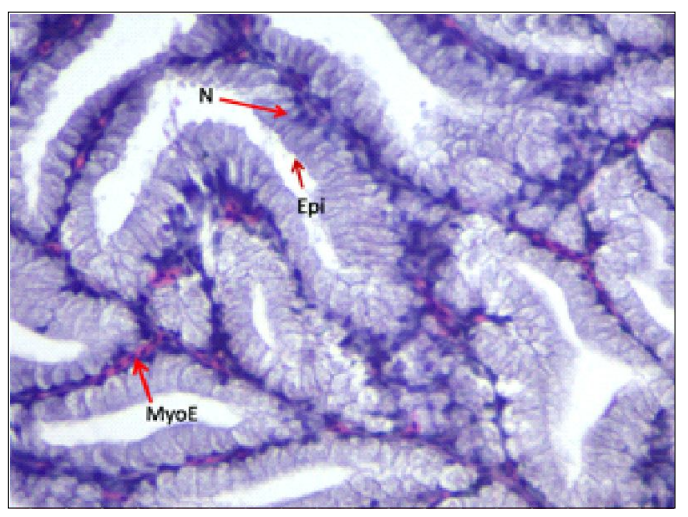

Fig 8: Photomicrograph showing the Epithelial (Epi) and Myoepithelial cells (MyoE) of the Harderian gland of Pati duck of 16 weeks (H\&E, 40X).

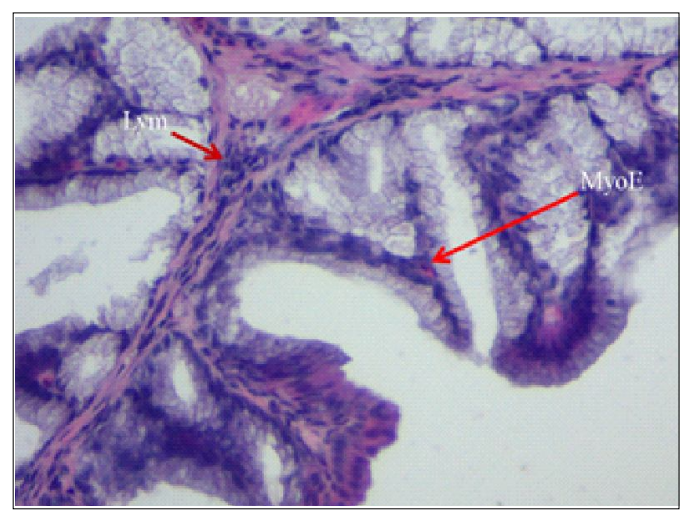

Fig 9: Photomicrograph showing the lymphocyte infiltration (Lym), myoepithlial cells (MyoE) in inter tubular area of harderian gland of 24 weeks (H\&E, 40X).

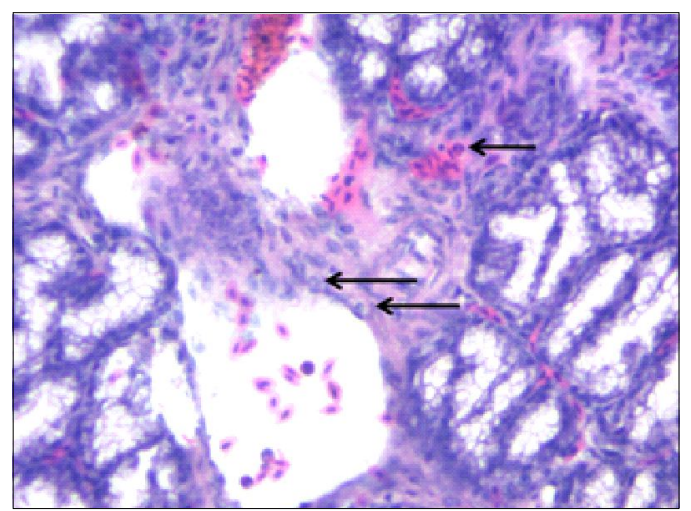

Fig 10: Photomicrograph showing the plasma cells in the inter tubular space of the harderian gland of Patiduck of 16 weeks.

(H\&E, 40X).

Harderian of the turkey, fowl and Duck lined by single layer of epithelium and the cells varied from cuboidal to columnar. Klećkowska-Nawrot et al. (2015) described about the Harderian gland of Ostrich (Struthio camelus domesticus) that the primary ducts were lined by a single layer of high columnar epithelial cells with spherical or oval nuclei 


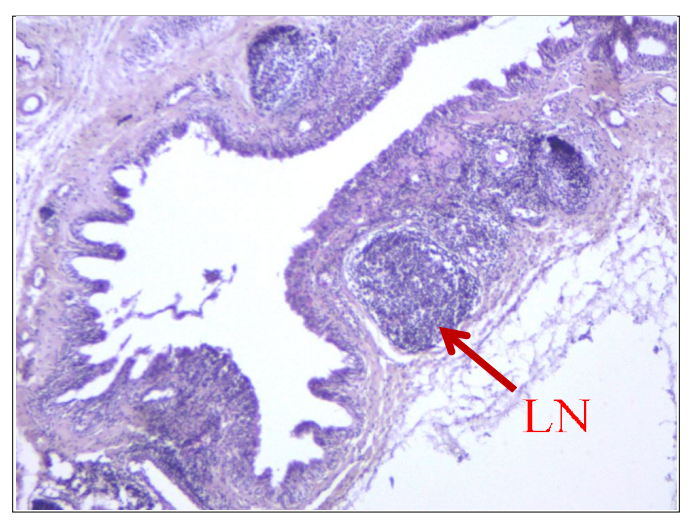

Fig 11: Photomicrograph showing lymphatic nodule (LN), Lumen of the duct of the Harderian gland of Pati duck of 42 weeks. (H\&E, 10X).

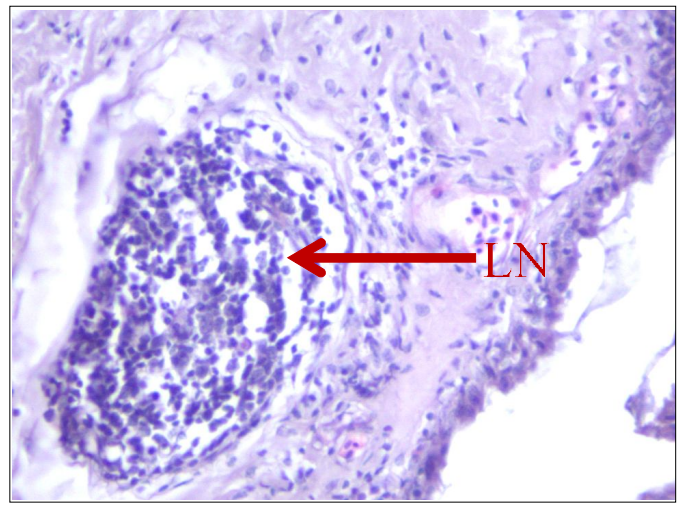

Fig 12: Photomicrograph showing lymphatic nodule of the duct of the Harderian gland of Pati duck of 42 weeks. (H\&E, 40X).

concentrated near the base of the cell and the secondary ducts were lined by cuboidal cells. Boydak and Aydin. (2009) also reported in the Harderian Gland of domestic geese that nuclei of myoepithelial cells were present at the base of the ductal epithelium. In the present the study, it was observed that the tunica muscularis of the duct of the Harderian gland consisted of smooth muscles, inner circular and outer longitudinal thin layers (Fig 12). The tunica serosa was blended with the surrounding orbital fascia. There were few lymphatic nodule very distinctly present extended from the lamina propria to tunica musculosa. The lymphocytes were very densely packed with in the nodule and germinal centre was not observed so far. Burns and Maxwell, (1979) observed the similar findings in the duct of the Harderian of the turkey, fowl and Duck. Mobini, (2012) reported in native Chicken that there were crypts along the duct and solitary lymphoid nodules were present near the crypts but the germinal centres were not evident.

\section{CONCLUSION AND SUMMARY}

The Harderian gland of Pati duck was covered by a capsule which was consist of connective tissue, blood vessels, nerves and lymphatices. The thickness of the capsule of the Harderian gland was increased slightly along the advancement of the age i.e. from 0 week to 42 week age group. The capsular connective tissue penetrated the parenchyma of the Harderian gland in the form of septa. The average thickness of the capsule of the Harderian gland of Pati duck had shown an increasing trend along with the advancement of age. The collagen, reticular and elastic fibers were observed along with the capsule and as well as in the septa and trabeculae and distribution was more prominent along the advancement of the age but decreased from capsule to inter lobular septa towards the centre of the gland. The nerve cylinders of the Harderian gland were noticed along with the capsule, inter lobar and interlobular connective tissue.

The Harderian gland of the Pati duck (Anas platyrhynchos domesticus) was compound tubular gland. From the capsular connective tissue of the periphery, the primary tubules were radiating towards the inner side of the gland. Then the secondary tubules emerged from the primary tubules and the tertiary tubules from the secondary tubules. There was no cortex and medulla in the gland and the tubular structures were uniformly distributed within the lobules. There was a central cannel which converged to the main duct of the gland. The lymphocyte, plasma cells were observed in the inter tubular connective tissue and density of these cells were more towards the central cannel and increased along with advancement of age. The myoepithelial cells with spindle shaped nucleus were present near the basement membrane close to the secretory cells. The histology of the duct of the Harderian gland of Pati duck was as that of typical hollow tubular organs. The lining epithelium was columnar varying in height. There were few lymphatic nodules extended from the lamina propria to the tunica muscularis.

\section{REFERENCES}

Ahmed, A. El Mansi, Dalia, A. Sabry, Yosra, A. Fouda. (2016). Development of eye regions and Harderian glands in young Chameleo chameleonv. Int. J. Adv. Res. Biol. Sci. 3(3): $57-67$.

Ali, F.R., Ilaf, H.H. and Hadaf, H.M. (2016). Morphological and histochemical study of harderian gland of domestic pigeon (Columba livia domestica). Bull. Iraq nat. Hist. Mus. 14 (2): 161-170.

Altunay, H. and Kozlu, T. (2004). The fine structure of the Harderian gland in the Ostrich (Struthio camelus). Anatomia Histologia Embryologia. 33: 141-145.

Bejdic, P., Avdic, R., Amidzic, L., Cutahija, V., Tandir, F. and Hadziomerovic, N. (2014). Developmental changes of lymphoid tissue in the harderian gland of laying hens. Mac. Vet. Rev. 37(1): 83-88.

Bejdic, P., Avdic, R., Amidzic, L.J., Cutahija, V., Tandir, F., Hadziomerovic, N., Katica, A., Mlaco, N. (2018). Ultrastructure of plasma cells in harderian gland of laying hens. Anat. Histol. Embryol. 47: 46-50.

Boydak, M. and Aydin, M.F. (2009). Histology of the Harderian gland of domestic geese (Anser anserdomesticus). Acta Vet Brno. 78: 199-204. 
Brobby, G.W. (1972). On the Harderian gland of the domestic duck (Anas platyrhynchos). Morphological and histochemical investigations. Z. Zellforsch. Mikrosk. Anat. 133: 223-230.

Burns, R.B. and Maxwell, M.H. (1979). The structure of the Harderian and lacrimal gland ducts of the turkey, fowl and duck. A light microscope study. J. Anat. 128(2): 285292.

Chieffi, G., Baccari, G.C., Di Matteo, L., D'Istria, M., Minucci, S. and Varriale, B. (1996). Cell biology of the Harderian gland. International Review of Cytology. 168: 1-80.

Dimitrov, D. (2012). Histometry of third eyelid (Harderian) gland in helmeted guinea fowl (Numida meleagris). Agricultural Science and Technology. 4 (4): 368-370.

Gracy, J.F. (1986). Bleeding Method of Slaughtering-Slaughter. Meat Hygiene. $8^{\text {th }}$ Edn. pp. 144-145.

Harder, J.J. (1694). Glandula nova lachrymalis una cum ductu excretorio $n$ cervis et damis. Acta Eruditorum Lipsiae. 49-52.

Indu, V.R., Lucy, K.M., Sreeranjini, A.R., Maya, S., Ashok, N. and Chungath, J.J. (2014). Gross and histological studies on the harderian gland of white pekin ducks (Anas platyrhynchos). Indian Journal of Veterinary Anatomy. 26 (1): $25-26$.
Kalita, N., Barua, N.; Bhuyan, J. and Chidananda, B.L. (2009). Present status of duck farming in Assam. Proceeding of IV world waterfowl conference held at Thrissur, Kerala, India, 11-13 Nov, pp. 359-363.

Kleckowska-Nawrot, J., Chec, A., Gozdziewska-Harlajczuk, K., Nowaczyk, R. and Barszcz, K. (2015). Light and electron microscopic studies of the harderian gland in bilgorajska goose (Anser Anser). Acta Biologica Hungarica. 66(3): pp. 249-257. DOI: 10.1556/018.66.2015.3.1.

Kozlu, T., Bozkurt, Y.A., Altunay, H. and Sari, E.K. (2010). Histological and histochemical studies on the Harderian gland of the osprey (Pandion haliaetus). Journal of Animal and Veterinay Advances. 9: 1875-1879.

Liman, N. and Gulmez, N. (1996). The light microscopic examinations on the development of the Harderian gland of the Geese (Anser anser). Ankara Univ. Vet Fak. Derg. 43: 25-30.

Luna, L.G. (1968). Manuals of Histological Staining Methods of Armed Forces Institute of Pathology, Mc Graw Hill Book Co., London. $3^{\text {rd }}$ Edn. pp. 79-207.

Mobini, B. (2012). Histological and Histochemichal studies on the Harderian gland in native chickens. Veterinarni Medicina. 57(8): 404-409.

Payne, A.P. (1994). The Harderian gland: A Tercentennial Review. Journal of Anatomy. 185: 1-49. 